\title{
The Factor of Intention to Buy Snacks Labeled Halal on Muslim Students in Yogyakrta
}

IQTISHADIA

12,2

211

\author{
Riyanto Efendi \\ Yogyakarta State University, Indonesia \\ riyantoefendi61@gamil.com \\ Sukidjo \\ Yogyakarta State University, Indonesia \\ sukidjo@uny.ac.id \\ Setyabudi Indartono \\ Yogyakarta State University, Indonesia \\ setyabudi_indartono@uny.ac.id
}

\begin{abstract}
In the industrial era 4.0 as it is now making the food industry increasingly diverse and easy to reach all walks of life. Food consumed by the community must be good and healthy because every time it is circulated it does not necessarily make it healthy and does not have a halal label. That way, the Muslim community certainly must choose foods that are good, healthy, and halal for consumption. So the purpose of this study was to determine the effect of subjective norms, perceptions of behavioral control, and religion on the intention to buy halal labeled snacks for Muslim students. Methodology This study was a quantitative study involving 174 students taken with the Snowball Sampling technique. Methods of multiple linear regression data analysis using SPSS Version 20. The results of the study are as follows: (1). Subjective norms have a positive and significant effect on the intention to buy snacks for Muslim students, (2). The perceived behavioral control has a positive and significant effect on the intention to buy snacks for Muslim students, (3). Reliability has a positive and significant effect on the intention to buy snacks for Muslim students, (4). Subjective norms, perceptions of control, and Religiosity jointly influence the intention to buy snacks products labeled halal $36.8 \%$.
\end{abstract}

\section{Keywords:}

Intention buy, Subjective norm, Perception behavioral control, Religiosity, Halal.

\section{INTRODUCTION}

The development of advanced technology in the industry era 4.0 as it now makes people's lives easier to find out information that they need in fulfilling their daily lives whether for consumption or other needs. The

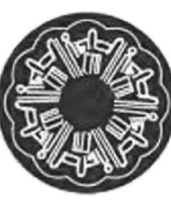

IQTISHADIA Vol. 12 (2) 2019 PP. 211-226

P-ISSN: $1979-0724$ E-ISSN: $2502-3993$ 
IQTISHADIA

12,2

212

need for consumption in order to establish a life process which is one of the characteristics and characteristics of humans as living things (Suyitno, 2005). food is a basic human need that is needed and requires good and right management in order to benefit the human body itself (Jordan, 2014).

Regarding consumption, the Muslim community in Islam has clearly regulated food and beverages that are halal and haram for consumption. Halal food and drinks are included as follows: 1). How to accept halal; 2). Foods and beverages that are truly halal for consumption (Hasbiyallah, 2006). According to Al-Quran Surah Al-Baqarah verses 168-169, "Halal means something that is permitted and permitted to be used based on Islamic law".

In the Republic of Indonesia, the food labeled Halal is usually printed on the food packaging itself. Based on Government Regulation of the Republic of Indonesia No. 69 of 1999 Article 1 paragraph 5 explains halal food is "Food that does not contain elements or ingredients that are unclean or prohibited for consumption by Muslims, both concerning food raw materials, food additives, auxiliary materials and auxiliary materials others include materials that are processed through the process of genetic engineering and food irradiation, and whose management is carried out in accordance with the provisions of Islamic religious law ". The food label contains at least the information as follows: 1). Product name; 2). List of materials used; 3). Net weight or clean contents; 3 ). The name and address of the producing factory or the company entering food into the territory of Indonesia; 5). Date, month, and year have expired. (PP No 69, 1999)

With the clear label halal on food packaging and added technological development, it will make it easier for all to choose and determine consumption that is good, healthy, and adds to the knowledge of each individual. Good experience from experience and exposure to information about halal products (Simanjuntak and Muhammad, 2014). Religion has important importance in terms of food consumption for Muslims in Islamic countries or non-Muslim countries (Sukesti and Budiman, 2014). Consuming halal food has become part of the lifestyle of people across religions who regard halal food as a healthy and good food for the body, no-Muslim residents in Europe consider halal food safe and healthy food (Ahmad et al., 2015).

Huda and Muchlisin (2014) found that all students pay attention to the halal label on the food requested on the food packaging. While Mukhtar and Mohsin (2012) found facts in choosing halal products requested by subjective norms and religiosity attitudes. While in another study found that perceived 
behavioral control had a significant influence on student consumption intentions (Rahmah, 2011).

Based on various phenomena and findings that can be conceptualized in consumption, specific consumption for the community, Muslims use various factors such as halal labels, subjective norms, religiosity, and perceived behavioral control. The purpose of this study was to study the effect of subjective norms, control of perceived behavior, religiosity on the intention to buy halal labeled snacks for Muslim students. How can it contribute to public audiences and it is important for food companies to get attention NoNo Starting from product ingredients and packaging so that it can provide a sense of security for consumers, especially the Muslim community.

\section{LITERATURE REVIEW}

\section{Intention To Buy}

The intention is defined as "the intention is assumed to see greater motivation factors influence motivation; that is the difficult difficulty of people in trouble (Ajzen, 1991). The intention has four aspects according to Fishbein and Ajzen (1975), namely as follows: 1). Behavior; 2) Target; 3). Situation; 4). Time. The intention to buy is something that is related to the customer's plan to buy a particular product and the number of units of the product needed at a certain period (Howard, 1994).

The intention to buy is also a buying buyer to buy a brand that takes buy buying that buys (Assael, 1998). According to Belch and Belch (2004), purchase intention is the choice to buy a brand and in general according to the motive between purchases with attributes or characteristics of the brand that can be chosen. While other opinions regarding purchase intention are interactions carried out by consumers with external factors and then become purchasing decisions based on characteristics and decision-making processes by consumers (Kotler, 2012).

The indicators of purchase intention are five components, namely as follows: 1). Interested in finding information about products; 2). Consider buying; 3). Interested in buying; 4). Want to know the product; 5). Want to have a product, (Schiffman and Kanuk, 2000). The buying decision-making process refers more to consistent and prudent actions taken to meet needs (Eagly and Chaiken, 1995). The decision-making process has five stages: 1). Introduction to problems; 2). Information search; 3). Alternative evaluation; 4). The decision to buy; 5). Behavior after buying, (Kotler and Armstrong, 2008). 
IQTISHADIA

12,2

214

\section{Subjective Norm}

Fishbein and Ajzen (1975) explain subjective norms are individual beliefs to do a behavior whether it is not. Subjective norms recommend referrals from individuals or groups of other individuals in carrying out actions or taking such references (Nilsson et al, 2004). Subjective norms encourage social demand for individuals to do or not take various actions (Rhodes and Courmeya, 2003). Supporting the Environment that supports him to do what he wants, then the individual will be very likely to carry out this behavior (Alam and Sayuti, 2011).

Ajzen (2005) states that subjective norms are functions based on Normative Belief and Motivation to Comply). Research conducted by Kapantouw and Mandey, (2015); Binalay et al (2016); and Cahyono, (2018); found that subjective norms have a positive and significant effect on buying intentions. Research conducted by Bonne et al. (2009) found that subjective norms were considered as part of the habit and became an independent variable that influenced the intention to buy halal meat. Research by Pepper et al (2010) and Lada et al. (2010) found that subjective norms were the most influential predictors of purchase intention. Subjective norms have a large influence on the intention to buy determined by the level of subjective norms on the concept of halal food. (Azziz et al., 2013).

Based on the results of several findings the hypothesis was developed:

H1: Subjective norms positively and significantly influence students' intention to buy halal labeled snacks.

\section{Perceived Behavioral Control}

A person's attitude towards halal food comes from their belief that the food is halal so that it will encourage them to carry out a positive attitude that is having the intention to make a purchase (Ajzen, 1991). In other words behavioral control regarding the presence or absence of factors that support or hinder an individual to bring up a behavior. Ajzen (2002) states that behavioral control influences the intention of assuming that behavioral control perceived by individuals will have motivational implications for that person. Perceived behavioral control affects directly or indirectly through intentions towards behavior (Ajzen, 1991).

Behavior control according to Ajzen (1991) is determined by a combination of beliefs about supporting or inhibiting factors for a behavior (control beliefs), with the strength of individual feelings about each of the 
supporting or inhibiting factors (Perceived power control). Control beliefs that give birth to perceived behavioral control our beliefs about the existence of things that support or inhibit the behavior that will be displayed and their perceptions of how strongly things support and inhibit perceived power.

Perception control behavior has a strong impact on consumer intentions The Factor of Intention and consumers who have a higher positive attitude will have a greater intention to buy halal food (Alam and Sayuti, 2011). Research conducted by Cahyono, (2018); and Ariyanto (2018) found that perceived behavioral control had a positive and significant effect on the intention to buy halal products. Other supporting research conducted by Mukhtar and Butt (2012) shows that individual behavior attitudes have a positive influence on the intention to buy halal products.

Based on the results of several findings the hypothesis was developed:

H2: The behavior of perceived control has a positive and significant effect on the intention to buy halal labeled snacks for students

\section{Religiosity}

Religion comes from the words re and ligare, which means reconnecting the broken ones if studied further means reconnecting humans and their gods, which is commonly called religion (Sangadah, 2015). Religion means the bonds that must be held and obeyed by humans (Nasution, 1985). Religion in the life of an individual function as a value that contains certain norms and in forming a system of values in the individual is by religion (Jalaluddin, 2010: 226).

Religion is behavior towards religion in the form of appreciation of religious values which is characterized by obedience in carrying out ritual worship and beliefs, experiences, and knowledge about the religion they embrace (Ancok and Suroso, 2008). Religiosity according to Glock and Stark (1970) is the level of one's knowledge of the religion they embrace and a level of overall understanding of the religion they embrace. The difference between religion and religiosity is religion or religion refers to the formal aspects related to rules and obligations, while religiosity refers to aspects of religion that are more internalized by individuals in the heart or in other words appreciation and practice of an individual towards religious teachings he adheres to (Mangunwijaya, 1982).

Jusmaliani and Hanny (2009) state that religiosity is one aspect of culture that refers to consumers. There are already religions that play an 
IQTISHADIA

12,2

216

important role in terms of food consumption for Muslim societies in Islamic or non-Islamic countries (Sukesti and Mamdukh, 2014: 150). Then the nature of religiosity of an individual will affect someone in the intention to buy and buy halal food products. The more religious, consumers will be as much as possible to buy halal food and spend it to engage in various activities that conflict with religious guidelines (Schneider et al, 2011; Masnono, 2005).

In the development of religiosity there are several factors that influence the target: 1). Internal factors are factors that arise from someone who drives someone to Allah SWT, 2). External factors are factors that contain a family environment in which a system of social life is debated and is the place where children first learn about various things, one of which is religious (Jalaluddin, 2010).

According to Glock and Stark (1970) dimensions of religion, there are five kinds of them, namely: 1). Belief or ideological dimensions, 2). Dimensions of religious or ritualistic practice, 3). Understanding or experiential dimensions, 4). The dimension of religious or intellectual knowledge, 5). Dimensions of practice or contribution. While the other dimensions of religiosity in Islam are: 1). The dimension of belief or creed, 2). Islamic or Islamic dimensions, 3). The dimension of experience or appreciation, 4). The dimension of knowledge or science, 5). Dimensions of practice or morals (Ancok and Suroso, 2011).

Religiosity has an orientation on consumers in choosing alternatives to food and food ingredients (Esoo and Dibb, 2004). Thus religiosity has an important role in influencing consumer relations (Mukhtar and Butt, 2012; Khraim, 2010). Religion has a significant war on the social life of people in the world including in choosing food (Awan et al., 2015).

According to Aliman and Othman (2007), although Muslims have a degree of adherence to different religious rules, in general, Muslims will have a positive attitude towards products that use a halal approach. The research conducted by Cahyono (2018) and Mutaalimah (2018) found that religiosity had a positive and significant effect on the intention to buy halal labeled products. The level of religiosity has a strong influence on consumer behavior and actions in purchasing halal food (Weaver and Agle, 2002). The level of someone's religiosity positively influences attitudes towards halal products (Mukhtar and Butt, 2012). A high level of religiosity will see the value of halallabeled food greater than consumers with low levels of religiosity (Jamal and Syarifuddin, 2014). 
Based on the results of several findings the hypothesis was developed:

H3: Religiosity has a positive and significant effect on the intention to buy halal labeled snacks for students.

Based on various explanations of the theory, the results of research findings, and the development of hypotheses regarding subjective norms, perceived behavioral control, religiosity towards buying intentions. Then the research framework is (Figure 1 ).

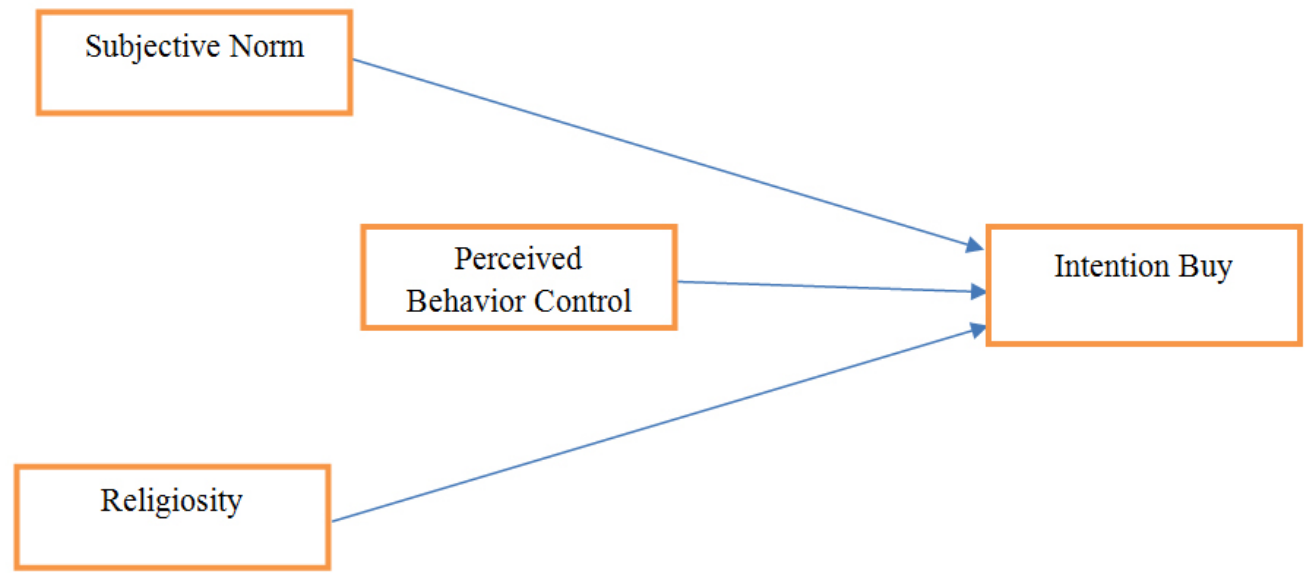

Figure 1: Research Framework

\section{RESEARCH METHOD}

This research is a type of quantitative research. Population data in this study came from S1 Muslim Students of the Faculty of Economics, Yogyakarta State University, with a total of 857 people spread across five study programs; office administration education, accounting education, economic education, accounting, and management.

The sample of this study was 174 people (Table 1), which was taken at $20 \%$ of the total contribution and based on the opinion of Arikunto (2010: 134) where if the research subject could take samples between $10-15 \%$ or $20-$ $25 \%$. The sampling technique used by snowball sampling is the initial sample selection technique, keep it small, then enlarge (Sugiyono, 2013: 125).

\section{Table 1. Population and Samples}

\begin{tabular}{ccc}
\hline Studi Program & Population & Sample \\
ADP Education & 167 & 32 \\
Accounting Education & 206 & 45 \\
Economic Education & 148 & 30
\end{tabular}




\begin{tabular}{ccc} 
Accounting & 168 & 33 \\
Management & 168 & 34 \\
Total & 857 & 174 \\
\hline
\end{tabular}

Source: Primary Data Processed

\section{RESULTS AND DISCUSSION}

Table 2 below is the result of a regression analysis of research data, with the results as follows:

Table 2. Results of Regression Analysis

\begin{tabular}{|c|c|c|c|}
\hline \multicolumn{4}{|c|}{ Koef. } \\
\hline Variable & $\begin{array}{l}\text { Regression } \\
\text { (B) }\end{array}$ & t statistic & Sig. \\
\hline Subjective Norm & 0,348 & 2,337 & 0,021 \\
\hline $\begin{array}{c}\text { Perceived Behavioral } \\
\text { Control }\end{array}$ & 0,227 & 3,128 & 0.002 \\
\hline Religiosity & 0,292 & 3,532 & 0,001 \\
\hline Konstanta & & 0,678 & \\
\hline $\mathrm{R}$ & & 0,606 & \\
\hline $\mathrm{R}^{2}$ & & 0,368 & \\
\hline F statistic & & 32,966 & \\
\hline Sig & & 0,000 & \\
\hline & $8+0,348+0,2$ & ,292 & \\
\hline
\end{tabular}

Source: Primary Data Processed

Based on the results of partial normalized regression analysis in influencing the intention to buy halal labeled snacks for Muslim students, the value of the regression coefficient was 0.348. At the $5 \%$ significance level, it is known that the value of $t$ count is 2,337 with a significance of 0.021 . With these results, the first hypothesis is accepted that subjective norms have a positive and significant effect on the intention to buy halal labeled snacks for Muslim students.

Based on the results of the research that has been analyzed there is a positive and significant influence that the subjective norm of the intention of 
buying light snacks labeled halal on Muslim students. This is indicated by the value of the regression coefficient of 0.348 . At the $5 \%$ significance level, it is known that the value of $t$ count is 2,337 with a significance of 0.021 . So it can be concluded that the higher the subjective norm, the higher the intention to buy halal labeled food products for Muslim students. Conversely, the lower The Factor of Intention the subjective norms of Muslim students, the lower the intention to buy halal labeled snacks.

These results are in accordance with the theory of planned behavior, namely the subjective norm of individual perceptions of social pressure to do or not carry out an activity that requires motivation. Every person who intends to do something related to other people who live in an important place and he experiences social pressure from social referrals to do so (Ajzen, 2005).

Based on the results of the study supported by the results of the research of Kapantouw and Mandey, (2015); Binalay et al. (2016); and Cahyono, (2018) which found subjective norms showed a positive and significant intention to buy. As well as research conducted by Bonne et al. (2009) found subjective norms chose as part of the habit and became an independent variable that influenced the intention to buy halal meat. Pepper et al. (2010) and Lada et al. (2010) 's research found that subjective norms became the most sought predictor in buying efforts. Changing subjective norms has a large interest in buying intention determined by the level of subjective norms on the concept of halal food. (Azziz et al., 2013).

Based on the results of the regression analysis, perceived control partially in influencing the intention to buy halal labeled snacks for Muslim students was shown the value of regression coefficient of 0.292. At the $5 \%$ significance level, it is known that the value of $t$ count is 3.128 with a significance of 0.002. With these results, the second hypothesis is accepted that perceived control has a positive and significant effect on the intention to buy halal labeled snacks for Muslim students.

Based on the results of the research that has been carried out it proves that the perceived and positive control behavior towards the intention of buying halal labeled snacks for Muslim students. This determines the regression coefficient of 0.292. At the significance level of $5 \%$, the value of $t$ count is 3.128 with a significance of 0.002 . So it can be concluded, the higher the perceived behavioral control, the higher the intention to buy halal labeled food products for Muslim students. Higher, lower perceived control behavior of Muslim students, the lower the intention to buy halal labeled food products. 
IQTISHADIA

12,2
These results indicate that control of customers and consumers who have a positive attitude will be higher will have a greater intention to buy halal food (Alam and Sayuti, 2011). The results of this study are also in accordance with those found by Cahyono, (2018); Ariyanto, (2018); Nurcahyo and Hudrasyah, (2017) stated that behavioral control was felt positively towards someone's intention to buy halal products. The results of the same study were also found by Mukhtar and Butt (2012) and Omar et al. (2012) where perceived behavioral control was positively related to the intention to buy halal products.

Based on the results of the partial religiosity regression analysis in influencing the intention to buy halal labeled snacks for Muslim students to obtain a regression coefficient of 0.227 . At the significance level of $5 \%$, the value of $t$ count is 3.532 with a significance of 0.001 . With these results, the third hypothesis is accepted as positive and significant religiosity towards the intention to buy halal labeled snacks for Muslim students.

R Square determination coefficient is used to show a large number of subjective norm variables, perceived behavioral control, and relationships together in influencing the variable intention to buy halal labeled snack products. The results of multiple regression analysis indicate that determination coefficient R2 has a value of 0.368 or it can be agreed that $36.8 \%$ of the intention to buy halal-grain snacks is needed by subjective norm variables, perceived behavioral control, and religiosity. While the remaining 63.2\% was approved by other variables not included in this study.

Based on the results of research that has been analyzed about positive and significant religiosity towards the intention of buying halal labeled snacks for Muslim students. This determines the regression coefficient value of 0.227 . At the significance level of $5 \%$, the value of $t$ count is 3.532 with a significance of 0.001. So it is undeniable, the higher the religiosity of Muslim students, the higher the intention to buy mild halal labeled food products. The lower the religiosity of Muslim students, the lower the intention to buy halal labeled food products.

These results indicate that religiosity is one of the most important aspects in influencing consumers (Delener, 1994), and supports the opinion of Esoo and Dibb, (2004) that religiosity supports consumer relations in choosing food and food choices. Thus religiosity has an important role in influencing consumer relations (Mukhtar and Butt, 2012; Khraim, 2010). In addition, religion has a significant war in the social life of people in the world including in choosing food (Awan et al., 2015; Ahmad, et al., 2013). 
This also supports the results of research which state that a person's level of positive religiosity will provide support for attitudes towards halal products (Mukhtar and Butt, 2012). The research conducted by Cahyono (2018) and Mutaalimah (2018) also found that religiosity had a positive and significant effect on the intention to buy halal labeled products. Aliman The Factor of Intention and Othman (2007) also discuss Muslims who have a high level of trust in religious differences, as a whole Muslims will have a positive attitude towards products that use halal. Weaver And Agle, 2002).

\section{The Effect of Subjective Norms, Perceived Behavioral Control, and Religiosity on Intention to Buy Halal Labeled Snacks for Muslim Students}

The results of the study showed a fact that significant subjective norms, perceived behavioral control, and religiosity towards the intention to buy halal labeled snacks for Muslim students. This answers with the results of testing with the F test which obtained F count value of 32,966 with a significance value of $\mathrm{F}$ of 0,000 or $\mathrm{F}<0,05$. Whereas the coefficient of determination of $\mathrm{R}$ Square is used to indicate a large number of subjective variable variables, perceived behavioral control, and relationships together in influencing the variable intention to buy halal labeled snack products. The results of multiple regression analysis indicate that determination coefficient $\mathrm{R} 2$ has a value of 0.368 or it can be agreed that $36.8 \%$ of the intention to buy halal-grain snacks is needed by subjective norm variables, perceived behavioral control, and religiosity. While the remaining $63.2 \%$ was approved by other variables not included in this study.

\section{CONLUSION}

Based on the results and discussion in the study, we can conclude that; (1). Subjective norms have a positive and significant effect on the intention to buy snacks for Muslim students, (2). Perceived behavior control has a positive and significant effect on the intention to buy snacks for Muslim students, (3). Reliability has a positive and significant effect on the intention to buy snacks for Muslim students, (4). Subjective norms, perceived behavior control, and reliability jointly influence the intention to buy snacks products labeled as $36.8 \%$ and $63.2 \%$ are influenced by variables outside the research. Together with limitations in this research can be a reference material for future research in the future. 
IQTISHADIA

12,2

222

\section{References}

Ahmad, A.N., Rahman, A.A., and Rahman, S.A. (2015), “Assessing Knowledge and Religiosity on Consumer Behavior towards Halal Food and Cosmetic Products", International Journal of Social Sciene and Humanity, 5(1): 10-14.

Ahmad, M; Kadir, S; and Saleluddin, N, 2013, Perception and Behavior's of Muslims and Non-Muslims Towards Halal Products, Journal of Social and Development Sciences, (Juni 2013): 249-25.

Ajzen, I. (1991). The theory of planned behavior. Organizational behavior and human decision processes, 50(2): 179-211.

Ajzen, I. (2002). Perceived Behavioral Control, Self-Efficacy, Locus of Control, and The Theory of Planned Behavior. Journal of Applied Social Psychology, 32 (4): 665-683.

Ajzen, I. (2005). Attitude, Personality, and Behavior second edition. USA: Open University Press.

Alam, S. and Sayuti, N. (2011), “Applying the theory of planned behavior (TPB) in Halal food purchasing", International Journal of Commerce and Management, 21 (1): 8-20

Aliman, N.K. and Othman, M.N. (2007) "Purchasing Local and Foreign Brands: What Product Attributes Matter?”. Dipresentasikan dalam The 13th Asia Pacific Management Conference, Melbourne, Australia, 400-411

Ancok, D and Suroso, F.A (2008). "Psikologi Islami: Solusi Islam ata Problem Psikologi”. Yogyakarta: Pustaka Belajar.

Ancok, D and Suroso F. N. (2011). Psikologi Islami Solusi Islam Atas ProblemProblem Psikologi. Yogyakarta: Pustaka Pelajar

Arikunto. S. 2010. Prosedur Penelitian Suatu Pendekatan Praktik. Jakarta: PT Rineka Cipta

Ariyanto, D. (2018). Pengaruh Attitude, Subjective Norm, dan Perceived Behavioral Control terhadap Repurchase Intention E-Money. Jurnal Ilmu Manajemen (JIM), 6(4).

Assael, H. (1998). "Consumer Behavior and Marketing Action" edisi 5. Cincinatti, Ohio: South Western College Publishing. 
Awan, Hayat M., Siddiquei, Ahmad N., Haider, and Zeeshan. (2015) "Factors affecting Halal purchase intention - evidence from Pakistan's Halal food sector", Management Research Review, 38 (6): 640-66o.

Aziz, Yuhanis Abdul and Chok, Nyen Vui (2013), “The Role of Halal Awareness, The Factor of Intention Halal Certification, and Marketing Components in Determining Halal Purchase Intention Among Non-Muslims in Malaysia: A Structural Equation Modeling Approach”, Journal of International Food and Agribusiness Marketing, 25(1): 1-23

Belch. G. E., and Belch. M. A. (2004) "Advertising and Promotion an Integrated Marketing Communications Perspective”. New York

Binalay, A. G., Mandey, S. L., \& Mintardjo, C. M. (2016). Pengaruh Sikap, Norma Subjektif dan Motivasi terhadap Minat Beli Secara Online Pada Mahasiswa Fakultas Ekonomi dan Bisnis di Manado. Jurnal EMBA: Jurnal Riset Ekonomi, Manajemen, Bisnis dan Akuntansi, 4(1).

Bonne, K., Vermeir, I. and Verbeke, W. (2009), "Impact of religion on Halal meat consumption decision making in Belgium", Journal of International Food and Agribusiness Marketing, 21 (1): 5-26

Cahyono, D. (2018). Pengaruh Religiusitas, Norma Subyektif dan Perceived Behavioral Control Terhadap Niat Membeli Produk Makanan Ringan Berlabel Halal (Studi Pada Mahasiswa Universitas Muhammadiyah Purworejo). Segmen - Manajemen, 14(1B).

Delener, N. (1994). Religious contrasts in consumer decision behaviour patterns: their dimensions and marketing implications. European Journal of Marketing, 28(5): 36-53.

Eagly, A.H. and Chaiken, S. (1995), “Attitude strength, attitude structure, and resistance tochange”, Vol. 4, Erlbaum, Mahwah, NJ, 413-432

Fishbein, M. leek Ajzen (1975). Belief, attitude, intention and behavior: An introduction to theory and research, 181-202.

Glock, C.Y, and Stark, R. (1970). "Religion and Society in Tension”. San Fransisco: Rand McNally.

Hasbiyallah. (2006). Fikih. Bandung: Grafindo Media Pratama.

Huda N; and Muchlisin. (2014). Pengaruh Label Halal Pada Makanan Terhadap Konsumsi Mahasiswa Fakultas Agama Islam Universitas Muhammadiyah Surakarta. SUHUF, 26 (1): 57-66 
IQTISHADIA

12,2

224

Howard, J. A. (1994). "Buyer behavior in marketing strategy". Englewood Cliffs, N.J.: Prentice Hall.

Jalaluddin. (2010). Psikologi Agama. Jakarta: Rajawali Pers.

Jamal, A and Sharifuddin, J (2014). "Perceived value and perceived usefulness of halal labeling: the role of religion and culture.” Journal of Business Research, 68 (5): 933-941

Jusmaliani; and Hanny, N. (2009). Religiosity Aspect in Consumer Behaviour: Determinants of Halal Meat Consumption. Asean Marketing Journal, I (2).

Kapantouw, C., \& Mandey, S. L. (2015). Pengaruh Sikap, Norma Subyektif, dan Gaya Hidup terhadap Keputusan Pembelian Handphone Asus di Gamezone Computer Mega Mall Manado. Jurnal EMBA: Jurnal Riset Ekonomi, Manajemen, Bisnis dan Akuntansi, 3(2).

Khraim, H., (2010) "Measuring Religiosity in Consumer Research From an Islamic Perspective", Journal of Economic and Administrative Sciences, 26 (1): 52-78

Kotler, P. and Armstrong, G. (2008), Principles of Marketing, 1st Edition, Erlangga, Jakarta.

Kotler, P., and Keller, K.L. (2012). Marketing Management, edisi 14. Essex: Pearson Edition Inc

Lada, S., Geoffrey H.T., and Hanudin, A. (2010) "Predicting intention to choose halal products using theory of reasoned action", International Journal of Islamic and Middle Eastern Finance and Management, 2 (1): 66-76

Mangunwijaya, Y. B. (1982). Sastra dan Religiusitas. Yogyakarta: Kanisius

Masnono, A. (2005), "Factors influencing the Muslim consumer's level of confidence on Halal logo", Report by Department of Business Administration, University Sains Malaysia, Penang.

Mukhtar, A and Butt, M. (2012), "Intention to choose Halal products: the role of religiosity”, Journal of Islamic Marketing, 3(2): 108-120

Mukhtar, A; and Muhammad M. (2012). Intention to Choose Halal Product: The Role of Religiosity. Journal of Islamic Marketing, 3(2): 108-120.

Mutaalimah, S. (2018). Pengaruh Harga, Kualitas Produk dan Religiusitas Terhadap Perilaku Pembelian Produk Kecantikan Sariayu Berlabel Halal. Departement Universitas Islam Indonesia. 
Nasution H. (1985). Islam Ditinjau Dari Berbagai Aspeknya Jilid I. Jakarta: UI Press

Nilsson, A., C. V. Borgstede, and A. Biel, (2004) "Willingness to accept climate change strategies: The effect of values and norms", Journal of Environmental Psychology, 24 (3): 267-277.

Nurcahyo, A and Hudrasyah, H (2017) "The Influence of Halal Awareness, Halal Certification, and Personal Societal Perception toward Purchase Intention : A Study Of Instant Noodle Consumption of College Student in Bandung”, Journal of Business and Management, 6 (1): 21-31.

Omar, B., Rajikin, M. H., and Sulaiman, S. (2012). "Pemakanan dan Kesihatan”. Kuala Lumpur, Malaysia: Dewan Bahasa dan Pustaka Publisher.

Peraturan Pemerintah Indonesia Nomor 69 tahun 1999 tentang Label dan Iklan Pangan (pasal 1 ayat 5).

Pepper, M., Jackson, T., and Uzzel, D. (2010). "A Study of Multidimensional Religion Constructs and Values in the United Kingdom”. Journal for The Social Scientific Study of Religion, (49): 127-146.

Rahmah. (2011). Pengaruh Sikap, Norma Subjektif, dan Perceived Behavioral Control Terhadap Intensi Membeli Buku Referensi Kuliah Ilegal Pada Mahasiswa UIN Syarif Hidayatullah Jakarta. Skripsi. Jakarta: Fakultas Psikologi Universitas Islam Negeri Syarif Hidayatullah.

Rhodes, R.E. and Courneya, K.S. (2003), "Investigating multiple components of attitude, subjective norm, and perceived control: an examination of the theory of planned behavior in the exercise domain", British Journal of Social Psychology, 42 (1): 129-146.

Sangadah, Z (2015) "Manajemen Yayasan Sunan Kalijaga Kadilangu Demak Dalam Mengelola Wisata Religi”. Skripsi. Dipublikasikan. Fakultas Dakwah Dan Komunikasi. Universitas Islam Negeri Walisongo Semarang.

Schiffman, Leon G, and Leslie Lazar Kanuk. (2000). Consumer Behavior 7e, Int Edition. New Jersey: Prenhallindo.

Schneider, H., Krieger, J. and Bayraktar, A. (2011), "The impact of intrinsic religiosity onconsumers' ethical beliefs: does it depend on the type of religion?Acomparison of Christian and Moslem consumers in Germany and Turkey", Journal of Business Ethics, 2 (2) : 319-332.
The Factor of Intention

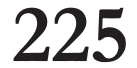


IQTISHADIA

12,2

Sugiyono. 2013. Metode Penelitian Pendidikan. Bandung: Alfabeta.

Sukesti, F; and Mamdukh, B. 2014. The Influence Halal Label and Personal Religiousity on Purchase Decision on Food Products in Indonesia. International Journal of Business, Economics and Law, 4 (1).

Suyitno. (2005). Ciri-ciri Makhluk. Dalam Pelatihan Pendalaman Materi IPA Cabang Dinas Kecamatan Kokap, Kulon Progo.

Weaver, G.R. and Agle, B.R. (2002), "Religiosity and ethical behavior in organizations: a symbolic interactions perspective", Academy of Management Review, 27 (1): 77-87

Yordani, A. (2014). Hygiene Sanitasi Makanan dan Minuman. Dalam http:// www.bbtklppbjb.freeiz.com/. Diakses pada hari Jum'at tanggal 15 Februari 2019 